\title{
Assessment of the Use of Solar Desalination Distillers to Produce Fresh Water in Arid Areas
}

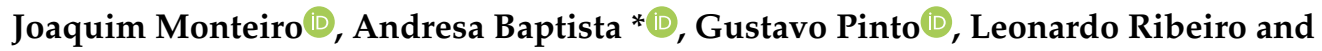 \\ Hélder Mariano
}

ISEP—School of Engineering, Polytechnic of Porto, 4200-072 Porto, Portugal; jfmo@isep.ipp.pt (J.M.); gustavopinto@eu.ipp.pt (G.P.); 1sr@isep.ipp.pt (L.R.); 1101342@isep.ipp.pt (H.M.)

* Correspondence: absa@isep.ipp.pt; Tel.: +351-228-340-500

Received: 27 November 2019; Accepted: 17 December 2019; Published: 19 December 2019

\begin{abstract}
Water is an important resource for human beings, yet there are inhabited places tormented by the scarcity of it. The present study is concerned with places where, seemingly, the best way to get water is through solar distillers. These places should have, typically, high values of solar irradiation and a lack of human and economic resources to build and operate complex equipment. A set of sites scattered around the world was chosen, and then the presumed productivity and thermal efficiency that solar distillers would have if they were installed at these places was calculated. The mathematical model used with this purpose assumes steady state operation; the values of mass of water distilled and distiller efficiency were calculated for every hour, but the results presented are annual averages. Then, an economic study was made based on local costs of construction materials for the distillers, the work force, and the prices of water to predict the payback time of solar distillers. Finally, a study on environmental impact, particularly in terms of greenhouse gas (GHG) emissions, was made to compare reverse osmosis (RO) with solar distillation. For the sites studied, typical values of annual water output are in the range of $414 \mathrm{dm}^{3} / \mathrm{m}^{2}$, for Évora, up to $696 \mathrm{dm}^{3} / \mathrm{m}^{2}$, for Faya Largeau; the minimum efficiency was found for Évora, as $11.5 \%$, and the maximum efficiency was found for Tessalit, as $15.2 \%$. Payback times are very high, regardless of the areas of the globe where solar distillers are implanted. Regarding the GHG emissions, solar distillation is preferable to RO.
\end{abstract}

Keywords: solar desalination; distillers; fresh water; arid areas; GHG emissions

\section{Introduction}

\subsection{Overview}

Needless to say, water is of paramount importance to almost all forms of life. Some think tanks concerned with geostrategic matters have even predicted that in the near future, wars will be waged because of lack of water.

The regions of the planet already distressed by water shortage are located in vast deserts in the north of Africa, Namibia, the outback of Australia, central Asia, North and South Americas, and some tiny islands in the middle of oceans. Moreover, because of climate change such places are appearing with increasing frequency.

It is not simply water that worries human beings, since water, namely, brackish water, is abundant and widespread; what worries human beings is the scarcity of fresh water. Yet, there are several ways to get fresh water from brackish water.

Desalination through distillation is a way to obtain fresh water from brackish or salted water. There are several methods to desalinate water, grouped by the authors of [1] as thermal and non-thermal; the current paper focuses only on the solar distillers, which follow a thermal method. The reason for 
this choice stems on the obvious link between water shortage and poverty, and so it seems realistic to desalinate water through simple and cheap methods, resorting to long-lasting facilities with almost no maintenance requirements, constructed with materials found locally; a solar distiller may last up to 25 years without major repairs [2].

Ultimately, a solar desalination distiller consists of a cover made of transparent material, placed over a basin filled with salted water (see Figure 1). According to Belessiotis et al. [1], the cover is normally roof-shaped, double-shaped, and symmetric, but can also be asymmetric or single sloped, and there can be two covers. Solar radiation successively crosses the cover; energy is absorbed by the water in the basin; water evaporates; and vapor rises to the underside of the cover, cooler than the upper side of the cover, condenses, and then slides, preferably without falling back into the basin, to the gutters bordering the distiller. The productivity of such installation is assessed by the mass of fresh water yielded by unit area of the distiller and unit of time.

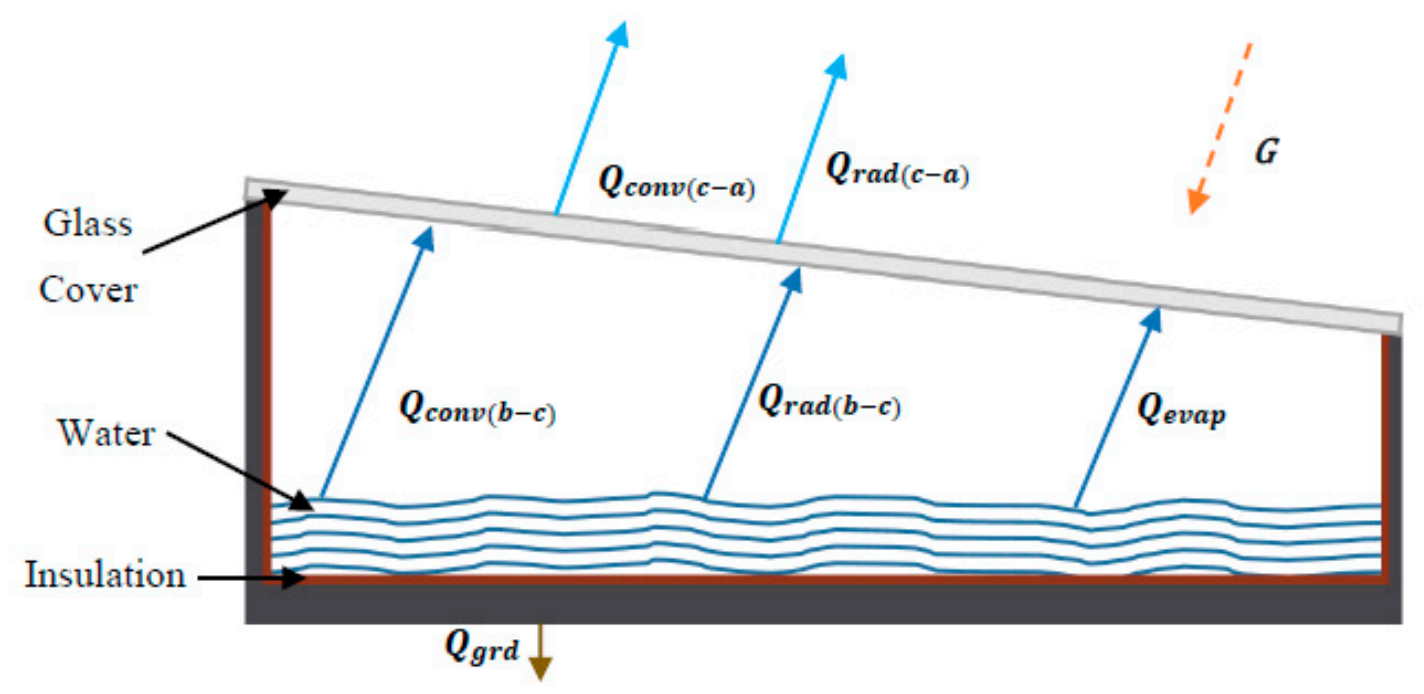

Figure 1. Schematic cross section of a typical solar distillation distiller.

The cover is usually of glass, and less often of plastic films. Glass covers have the drawback of being breakable and, according to the authors of [3], should have a hematite content lower than $0.01 \%$. Plastic covers can be made of treated polyvinylchloride and tetraphalate-polyethylene; their durability is less than 15 years, and their adaptability to any desired shape of the distiller is the highest of their class [1]. Phadatare and Verma [4] found that the productivity of distillers covered with glass is $30 \%$ to $35 \%$ higher than the productivity for distillers covered with Plexiglas.

The slope of the cover must guarantee that the condensed droplets of water, due to their surface tension, do not fall back into the basin but slide to the gutters, to be collected; this slope is normally under $20^{\circ}$ [2]. The gutters have a slight slope too, just enough to prompt the flow of the distilled water into a reservoir that feeds consumers of such water. If the basin is shallow, its depth ranges from 10 to $20 \mathrm{~mm}$; if the basin is deep, its depth goes up to $100 \mathrm{~mm}$ [4]. The widths are around $2 \mathrm{~m}$ and the lengths can reach $100 \mathrm{~m}[4]$.

The floor of the basin bottom liner must be waterproof, free of toxic components, withstand temperatures up to $90^{\circ} \mathrm{C}$, have a thermal absorptivity above 0.95 (see Table 1), and a polished surface. From Belessiotis et al. [1], it is normally made of one of these materials: concrete, wood impregnated with epoxy resins, aluminum, magnesium alloys, hard plastic ultraviolet resistant as Plexiglas, etc. To increase its absorption of solar heat, the upper side of the floor of the basin is covered by one of these materials: black paint (without volatile components that could evaporate with the water), spongy materials, butyl rubber, black polyethylene, asphalt, jute, etc. 
The frame that supports the glass/plastic cover has to be robust and cling to the ground to withstand inclement weather, such as sand storms, but some of its parts must be removable to allow cleaning and repairs in the distiller.

The bottom and sidewalls of the basin are insulated from the ground to lower, as much as possible, the heat losses from the distiller. The most suitable insulation materials have low conductivity, are easily applicable to this kind of basin, withstand the operation of the distiller without deformations, do not release chemicals harmful into water up to $90^{\circ} \mathrm{C}$, and are waterproof. Pumps, storage tanks, pipes, fittings, etc., are considered ancillary components. Pipes and fittings can be of the same material, such as polyvinyl chloride (PVC) or any other plastic material not damaged by temperatures up to $90^{\circ} \mathrm{C}$; pipes and fittings either of galvanized steel or copper for brackish water, and stainless steel for distilled water, can be used as well. Normally, plastic materials are cheaper than stainless steel.

The sealing between cover and basin is necessary because the volume limited by the surface of the water, the underside of the cover, and the tops of the distiller must be air tight to reduce convection losses. Good sealing materials are easily applied, non-toxic, and have very low absorptivity.

The maintenance requirements of such distillers are cheap and easy. The maintenance consists mostly in removing leaves, dust, and sand from the cover; occasionally glasses break, and then have to be replaced. Some parts must be removable to allow cleaning and repairs in the basin.

Such distillers must endure bad weather conditions, such as strong winds and sand storms.

Solar desalination distillers operate in either batch or continuous mode. In batch mode, the amount of water evaporated from the basin during one day is offset, at the next sunrise, by new salt water. To avoid scaling or algae, every two or three days the basin is emptied and then refilled with new saltwater. As the temperature of the water in the basin increases, the productivity of the distiller increases; this is the reason why during the morning and the night such productivity is low but near noon it is at a maximum. Besides, shallow basins do not store sensible heat as do deep distillers. The productivity of distilled water by shallow distillers is in phase with the value of irradiation received by the distiller and so, from sunset to sunrise, distillation stops; however, as deep distillers store heat, distillation extends after sunset, although at low rate. In continuous mode, the basin is continuously fed by saltwater in a way to keep the amount of water in the basin constant.

\subsection{Sites with Distillation Distillers}

There is a long record of facilities to desalinate water through solar distillation. Some of these plants are shown in in Table 1.

In 1872, such a desalination plant was built at Chacabuco, (Las Salinas, Chile), which is described in detail by the authors of [5-7]. It operated for three decades to provide drinking water for animals used in nitrate mining [5]. Additionally, at Daytona Beach (Florida, USA), a similar facility was built, operated by Battele Memorial Institute of Cleveland [8-10]. In addition, numerous studies have been published, such as that by the authors of [11-13].

The Table 2 contains some sites, scattered around the world, which are seemingly suitable to solar harnessing facilities in general. The purpose of the present work is to assess the performance of specific distillation plants eventually set up on such sites. 
Table 1. Features of solar distillation plants.

\begin{tabular}{|c|c|c|c|c|c|c|}
\hline Country & Sites & Construction Year & Basin Area $\left(\mathrm{m}^{2}\right)$ & Production (L/day) & Daily Production Per Area $\left(\mathrm{L} / \mathrm{m}^{2}\right)$ & Reference \\
\hline \multirow{6}{*}{ Australia } & Muresk I & 1963 & 372 & 833 & 2.24 & [14-16] \\
\hline & Muresk II & 1966 & 372 & 833 & 2.24 & [15-18] \\
\hline & Coober Pedy & 1966 & 3159 & 6359 & 2.01 & [15] \\
\hline & Caiguna & 1966 & 372 & 776 & 2.09 & [19] \\
\hline & Hamelin Pool & 1966 & 557 & 1211 & 2.17 & {$[10,20]$} \\
\hline & Griffith & 1967 & 413 & 908 & 2.20 & {$[10,20]$} \\
\hline Cabo Verde & Santa Maria & 1965 & 743 & 2120 & 2.85 & {$[10,20]$} \\
\hline \multirow{2}{*}{ Caribbean } & Petit St. Vincente & 1967 & 1709 & 4921 & 2.88 & [19] \\
\hline & Haiti & 1969 & 223 & 757 & 3.39 & {$[10,20]$} \\
\hline \multirow{2}{*}{ Chile } & Las Salinas & 1872 & 4459 & 14,763 & 3.31 & {$[6,21]$} \\
\hline & Quillagua & 1968 & 100 & 401 & 4.01 & [22] \\
\hline \multirow[t]{2}{*}{ Spain } & Las Marinas & 1966 & 869 & 2574 & 2.96 & [23] \\
\hline & Daytona Beach 1 & 1959 & 228 & 530 & 2.32 & [24] \\
\hline \multirow{3}{*}{ USA } & Daytona Beach 2 & 1959 & 216 & 379 & 1.75 & {$[24,25]$} \\
\hline & Daytona Beach 3 & 1961 & 246 & 568 & 2.31 & [25] \\
\hline & Daytona Beach 4 & 1963 & 149 & 606 & 4.07 & {$[10,20]$} \\
\hline \multirow{6}{*}{ Greece } & Symi & 1964 & 2687 & 7571 & 2.82 & {$[26,27]$} \\
\hline & Aegina & 1965 & 1490 & 4240 & 2.84 & [28] \\
\hline & Salamis & 1965 & 388 & 1098 & 2.83 & [20] \\
\hline & Patmos & 1967 & 8640 & 26,119 & 3.02 & {$[29,30]$} \\
\hline & Kimolos & 1968 & 2508 & 7571 & 3.02 & [20] \\
\hline & Nisiros & 1969 & 2044 & 6057 & 2.96 & [20] \\
\hline India & Bhavnagar & 1965 & 377 & 833 & 2.21 & {$[31,32]$} \\
\hline Mexico & California & 1969 & 95 & 379 & 3.99 & [20] \\
\hline \multirow{2}{*}{ Tunisia } & Chakmou & 1967 & 439 & 530 & 1.21 & [20] \\
\hline & Mahdia & 1968 & 1301 & 4164 & 3.20 & {$[20]$} \\
\hline USSR & Turkmenistan & 1964 & 599 & 1628 & 2.72 & [33] \\
\hline
\end{tabular}


Table 2. Sites studied at the present work chosen to assess their suitability to desalination through solar distillation plants.

\begin{tabular}{|c|c|c|c|c|c|c|}
\hline Sites & Country & Latitude $\left({ }^{\circ}\right)$ & Longitude $\left(^{\circ}\right)$ & Altitude (m) & $T_{m}$ Annual $\left({ }^{\circ} \mathrm{C}\right)$ & $G$ Annual (KWh $\left.\mathrm{m}^{-2} \mathrm{y}^{-1}\right)$ \\
\hline Al Fashir & Sudan & 13.6 & 25.3 & 729 & 25.0 & 2482 \\
\hline Almeria & Spain & 36.8 & -2.3 & 21 & 18.7 & 1880 \\
\hline Atar & Mauritania & 20.5 & -13.0 & 231 & 27.0 & 2404 \\
\hline Abu Rudeis & Egypt & 28.9 & 33.1 & 8 & 23.7 & 2223 \\
\hline Bilma & Niger & 18.7 & 12.9 & 357 & 26.4 & 2428 \\
\hline Dakha & Western Sahara & 23.7 & -15.9 & 10 & 19.7 & 2005 \\
\hline Dikhil & Djibouti & 11.1 & 42.3 & 490 & 25.3 & 2584 \\
\hline Évora & Portugal & 38.5 & -7.8 & 246 & 16.3 & 1849 \\
\hline Faya Largeau & Chad & 17.9 & 19.1 & 235 & 24.4 & 2456 \\
\hline Malakal & South Sudan & 9.5 & 31.6 & 394 & 26.7 & 2351 \\
\hline Massawa & Eritrea & 15.6 & 39.4 & 10 & 29.3 & 2184 \\
\hline Mekele & Ethiopia & 13.4 & 39.5 & 2254 & 16.5 & 2386 \\
\hline Mogadishu & Somalia & 2.0 & 45.3 & 3 & 27.0 & 2239 \\
\hline Santiago & Cabo Verde & 14.9 & -23.5 & 95 & 24.6 & 2245 \\
\hline St. Louis & Senegal & 16.0 & -16.4 & 2.7 & 25.19 & 2174 \\
\hline Tessalit & Mali & 20.2 & 0.97 & 494 & 27.8 & 2440 \\
\hline
\end{tabular}

\section{Analyses}

The solar distillation process to obtain water was analyzed in three respects: thermal efficiency, economics, and carbon emissions.

\subsection{Thermal Efficiency}

Belessiotis et al., Cooper, Duffie, and Beckman [1,2,5], among others, proposed two energy equations, one for the basin and another for the cover, with almost the same terms.

In the current study, the energy equation applied to the basin is

$$
G \tau_{c} \alpha_{w}-Q_{e v a p}-Q_{r a d(b-c)}-Q_{c o n v(b-c)}-Q_{g r d}=(M c / A)_{b} \frac{d T_{b}}{d t},
$$

where the subscripts $c, w, b$, and grd stand for cover, water, basin, and ground, respectively; the energy equation applied to the cover, neglecting the variation of internal energy and the solar energy absorbed by it, is

$$
Q_{\text {evap }}+Q_{\text {rad }(b-c)}+Q_{\operatorname{conv}(b-c)}=Q_{\operatorname{conv}(c-a)}+Q_{\text {rad }(c-a)} \text {, }
$$

where the subscript $a$ stands for the atmosphere. In the right-hand side of Equation (2), the sky is assumed as a plate.

Normally, for shallow and well-insulated basins, a steady-state operation can be assumed and, accordingly, the right-hand side of Equation (1) can be neglected.

According to Cooper [34], the total (all the wavelengths) and directional (angles of incidence of $0^{\circ}$, $30^{\circ}, 45^{\circ}$, and $60^{\circ}$ ) values of absorptivity, transmissivity, and reflectivity for the glass cover, the water in the basin and the basin liner are given at Table 3. The angle of incidence, $\theta$, is measured from the normal to the surface.

Dunkle [35] proposes that

$$
Q_{\text {rad }(b-c)}=0.9 \sigma\left(T_{b}^{4}-T_{c}^{4}\right)
$$

assuming that both the water surface and the lower side surface of the cover are diffuse and gray; the value of 0.9 includes the view factor between these surfaces and their emissivities.

For the evaporation

$$
Q_{\text {evap }}=9.15 \times 10^{-7} h_{c}^{\prime}\left(p_{w b}-p_{w c}\right) h_{f g}
$$

with

$$
h_{c}^{\prime}=0.884\left\{\left(T_{b}-T_{c}\right)+\left[\left(p_{w b}-p_{w c}\right) /\left(2016-p_{w b}\right)\right] T_{b}\right\}^{1 / 3}
$$


and the mass of water evaporated per unit of time is

$$
\dot{M}_{\text {evap }}=9.15 \times 10^{-7} h_{c}^{\prime}\left(p_{w b}-p_{w c}\right) .
$$

For the convection between the basin and the lower side surface of the cover

$$
Q_{\operatorname{conv}(b-c)}=h_{c}^{\prime}\left(T_{b}-T_{c}\right) .
$$

For the convection between the upper surface of the cover and the atmosphere, which is normally a mixture of free and forced convection, McAdams recommends to adopt the convection coefficient as the maximum between $5 \mathrm{Wm}^{-2} \mathrm{~K}^{-1}$ and the value obtained with $8.6 \mathrm{~V}^{0.6} \mathrm{~L}_{c}{ }^{-0.4}$; so

$$
h_{(c-a)}=\max \cdot\left[5 ; 8.6 V^{0.6} L_{c}^{-0.4}\right],
$$

with $V$ representing the velocity of wind, expressed in meters per second, and the characteristic length, $L_{c}$, representing the cube root of the volume of the distiller, expressed in meters. Then

$$
Q_{\operatorname{conv}(c-a)}=h_{(c-a)}\left(T_{c}-T_{a}\right) .
$$

The radiation exchange between the upper face of the cover and the sky is

$$
Q_{\operatorname{rad}(c-a)}=\varepsilon_{c} \sigma\left(T_{c}^{4}-T_{s k}^{4}\right) .
$$

The temperature of the sky was obtained by

$$
T_{s k}=T_{a}\left[0.711+0.0056 T_{w b}+0.000073 T_{w b}^{2}+0.013 \cos (15 t)\right]^{2} .
$$

The value of $Q_{g r d}$ is negligible, since it depends on the construction quality of the basin, which can be controlled by the builder of the basin; a well-insulated basin is usually assumed.

The performance of the distiller was assessed through the efficiency calculated with

$$
\eta=\dot{M}_{\text {evap }} / G
$$

\subsection{Economics}

In order to carry out the feasibility study of a project, it is very important to make an economic analysis of it. Firstly, this requires predicting expenditures (investments, costs, and expenses) and revenues and, secondly, the analysis of some economic indicators (TCO, NPV, IRR, and payback period). The presently studied facilities consist of distillers with an area arbitrarily set as $1 \mathrm{~m}^{2}$, and therefore the costs considered are per square meter of installation. Costs of components were obtained through the CYPE, a price generator digital platform [36].

Total cost of ownership (TCO) is a financial estimate designed to evaluate direct and indirect costs related to purchase and capital expenditures (CAPEX), in addition to operating and maintenance costs (OPEX), and can be expressed through

$$
T C O=C A P E X+O P E X .
$$

CAPEX covers only the cost of building the equipment. OPEX includes maintenance and operating costs, considering an annual inflation rate of $2 \%[37,38]$.

Considering that the equipment has a lifespan of 20 years, the cost of water per $1 \mathrm{~m}^{3}$ is given by

$$
\frac{\cos t}{m^{3}}=T C O /\left(M_{\text {evap-yearly }} \times n\right),
$$


with $n$ representing the operation years and $M_{\text {evap-yearly }}$ representing the mass of fresh water obtained yearly.

The net present value $(N P V)$ is the balance of all cash inflows and outflows over the estimated useful life of a project, updated to the present moment, considering an inflation rate for the stipulated period. NPV can be calculated using

$$
N P V=\sum_{n=0}^{n} F a_{n} R_{n}-\sum_{n=0}^{n} F a_{n} G_{n}
$$

where $F a_{n}$ is the update factor for period $n, R_{n}$ the revenue for period $n$, and $G_{n}$ the expenditure for period $n$.

The value of $F a_{n}$ is calculated through

$$
F a_{n}=\frac{1}{(1+i)^{n}}
$$

where $i$ is the inflation rate and $n$ the years of operation.

The internal rate of return (IRR) represents the return on an investment, expressed as a percentage rate. The IRR can be viewed as the rate required for NPV to be zero, and calculated by

$$
N P V=0=\text { Initial Investment }+\sum_{t=1}^{n} \frac{F_{n}}{(1+I R R)^{n}},
$$

where $F_{n}$ is the cash flow for period $n$.

The payback period represents the time it will take a project to generate returns that equal the investment, and can be calculated using

$$
\text { Payback }=\frac{\text { Investment }}{\text { Revenue } / \text { year }}
$$

Table 3. Total and directional values of absorptivity, transmissivity, and reflectivity for the glass cover, the water in the basin, and the basin liner; these values are presented in \% [34].

\begin{tabular}{ccccc}
\hline $\begin{array}{c}\text { Angle of } \\
\text { Incidence, } \boldsymbol{\theta}\end{array}$ & $\mathbf{0}^{\circ}$ & $\mathbf{3 0}^{\circ}$ & $\mathbf{4 5}^{\circ}$ & $\mathbf{6 0}^{\circ}$ \\
\hline \multicolumn{5}{c}{ Glass cover } \\
\hline Absorptivity, $\boldsymbol{\alpha}$ & 5 & 5 & 5 & 5 \\
Transmissivity, $\boldsymbol{\tau}$ & 90 & 90 & 89 & 85 \\
Reflectivity, $\boldsymbol{\rho}$ & 5 & 5 & 6 & 10 \\
\hline \multicolumn{5}{c}{ Water in the basin } \\
\hline Absorptivity, $\boldsymbol{\alpha}$ & 30 & 30 & 30 & 30 \\
Transmissivity, $\boldsymbol{\tau}$ & 68 & 68 & 67 & 64 \\
Reflectivity, $\boldsymbol{\rho}$ & 2 & 2 & 3 & 6 \\
\hline & Basin bottom (liner) & & \\
\hline Absorptivity, $\boldsymbol{\alpha}$ & 95 & 95 & 95 & 95 \\
Transmissivity, $\boldsymbol{\tau}$ & 0 & 0 & 0 & 0 \\
Reflectivity, $\boldsymbol{\rho}$ & 5 & 5 & 5 & 5 \\
\hline
\end{tabular}

\subsection{Carbon Emissions}

The parameter analyzed was the $\mathrm{CO}_{2 \mathrm{e}}$ emissions, defined by IEA 2018, corresponding to the production of $1 \mathrm{~m}^{3}$ of fresh water. This parameter only encompasses the $\mathrm{CO}_{2 \mathrm{e}}$ produced by the operation of getting fresh water. Two alternative scenarios were studied: (i) the production of water through reverse osmosis (RO), currently the most widespread desalination process [39], and (ii) the production of water through solar distillation, the process presently studied. Obviously, RO consumes 
electric energy unlike solar distillation. Other methods to get fresh water were excluded from this analysis due to their technical complexities or operational costs, which renders them inappropriate for small and poor communities, the main target of this study.

Table 4 contains values of total emissions of $\mathrm{CO}_{2 \mathrm{e}}$ and of the total electricity produced by the countries, where the sites studied are located. Specific emissions of $\mathrm{CO}_{2 \mathrm{e}}$ were calculated with both these values; these specific emissions depend on the energy mix of the country. Whenever there were no reliable values either of $\mathrm{CO}_{2 \mathrm{e}}$ emissions or the amount of electricity generated, counterpart values of the nearest country were assumed, such as in the cases of Atar, Dikhil, and Faya Largeau.

Table 4. Emissions of $\mathrm{CO}_{2 \mathrm{e}}$.

\begin{tabular}{ccccc}
\hline Sites & $\begin{array}{c}\mathbf{C O}_{2 \mathbf{e}} \text { Emissions } \\
\mathbf{( M t o n )}\end{array}$ & $\begin{array}{c}\text { Electricity } \\
\text { Generated (TWh) }\end{array}$ & $\begin{array}{c}\text { Specific Emissions of } \mathbf{C O}_{2 \mathbf{e}} \\
\mathbf{k g}_{\mathbf{C O}_{2 \mathbf{e}} / \mathbf{k W h}}\end{array}$ & Ref. \\
\hline Al Fashir & 6.2 & 15.5 & 0.400 & {$[41]$} \\
Almeria & 66.7 & 273.4 & 0.243 & {$[41]$} \\
Atar & - & - & 0.625 & - \\
Abu Rudeis & 89.3 & 188.2 & 0.474 & {$[41]$} \\
Bilma & 0.5 & 0.6 & 0.833 & {$[41]$} \\
Dakha & 21.6 & 32.8 & 0.658 & {$[41]$} \\
Dikhil & - & - & $1.000^{2}$ & - \\
Évora & 18.1 & 57.7 & 0.314 & {$[41]$} \\
Faya Largeau & - & - & $0.400^{3}$ & - \\
Malakal & 0.5 & 0.5 & 1.000 & {$[41]$} \\
Massawa & 0.4 & 0.4 & 1.000 & {$[41]$} \\
Mekele & 0 & 13.9 & 0 & {$[41]$} \\
Mogadishu & - & - & $1.000^{2}$ & - \\
Santiago & 0.2 & 0.4 & 0.490 & {$[40]$} \\
St. Louis & 3.0 & 4.8 & 0.625 & {$[41]$} \\
Tessalit & - & - & $0.625^{1}$ & - \\
\hline
\end{tabular}

${ }^{1}$ Value from Senegal, ${ }^{2}$ value from Eritrea, and ${ }^{3}$ value from Sudan.

Besides, in Cabo Verde, in the year of 2018 [40], the consumption of electricity to obtain potable water through $\mathrm{RO}$ was $3.909 \mathrm{kWh} / \mathrm{m}^{3}\left(31,684,028 \mathrm{kWh}\right.$ to get $8,106,322 \mathrm{~m}^{3}$ of potable water); it is plausible to assume this same value for other countries, whenever $\mathrm{RO}$ is concerned.

\section{Results}

\subsection{Thermal Efficiency}

Results concerning output were obtained for the locations indicated at Table 2, with climatic data drawn from reference [42], equations (1) and (2), and the assumption of steady state operation for the basin and the cover.

Hourly values of $Q_{e v a p}, \dot{M}_{\text {evap }}, Q_{\operatorname{conv}(b-c)}, h_{(c-a)}, Q_{\operatorname{conv}(c-a)}$, and $Q_{\operatorname{rad}(c-a)}$ were calculated with hourly values of $\mathrm{V}, T_{a}, T_{s k}$, and $T_{w b}$ drawn from the referred climatic site and with the above-mentioned equations, from (1) to (11). The values of absorptivity of water, transmissivity, and reflexivity of the glass cover were assumed as the averages of the homologous values contained at Table 3 . The unknowns were the temperature of the basin, $T_{b}$, and the temperature of the cover, $T_{c}$, determined by a solver for nonlinear equations. Lastly, hourly values of the efficiency of the solar distiller, $\eta$, were obtained as well. Annual values shown in the following graphs were calculated with the counterpart hourly values.

Figure 2 shows the annual output of distilled water for the sites studied, whereas Figure 3 shows the annual efficiency of solar distillation plants for the same sites. 


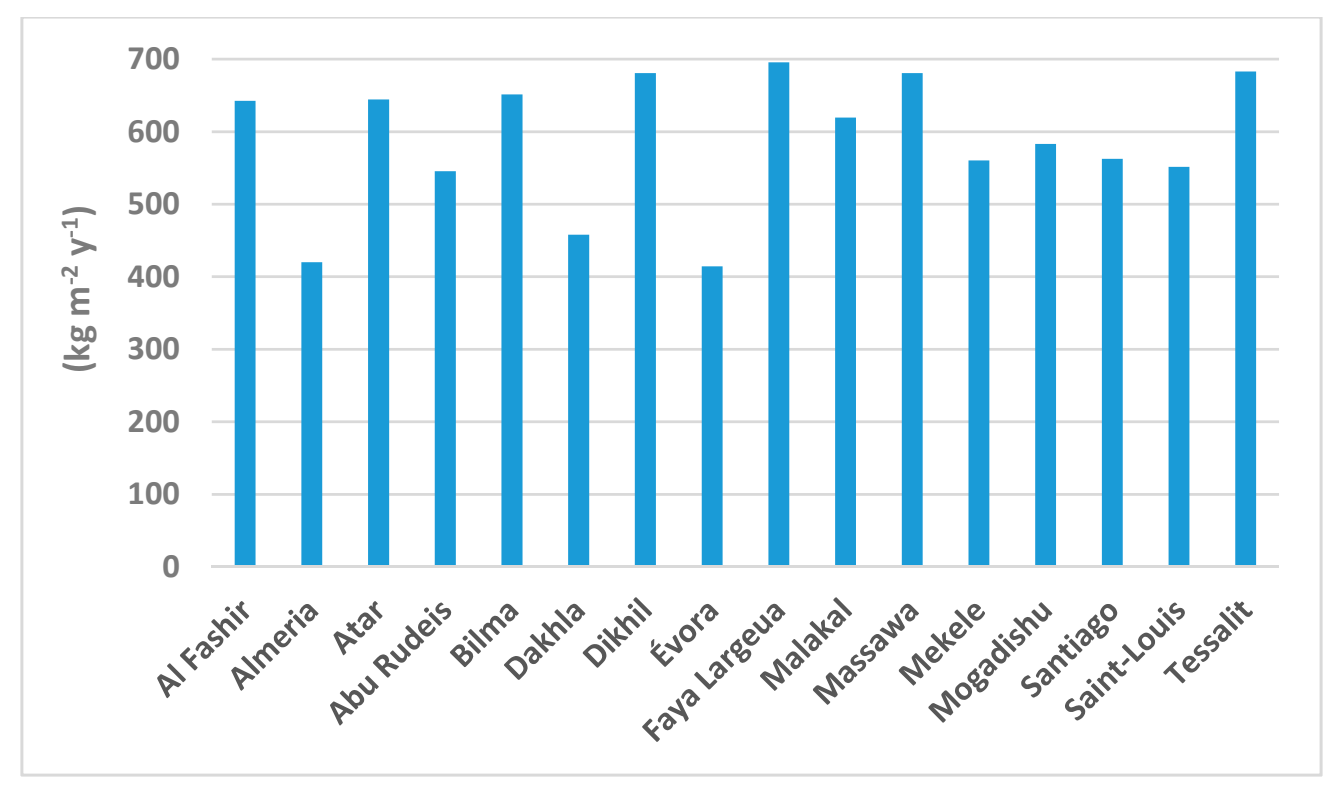

Figure 2. Annual output of distilled water for the sites studied.

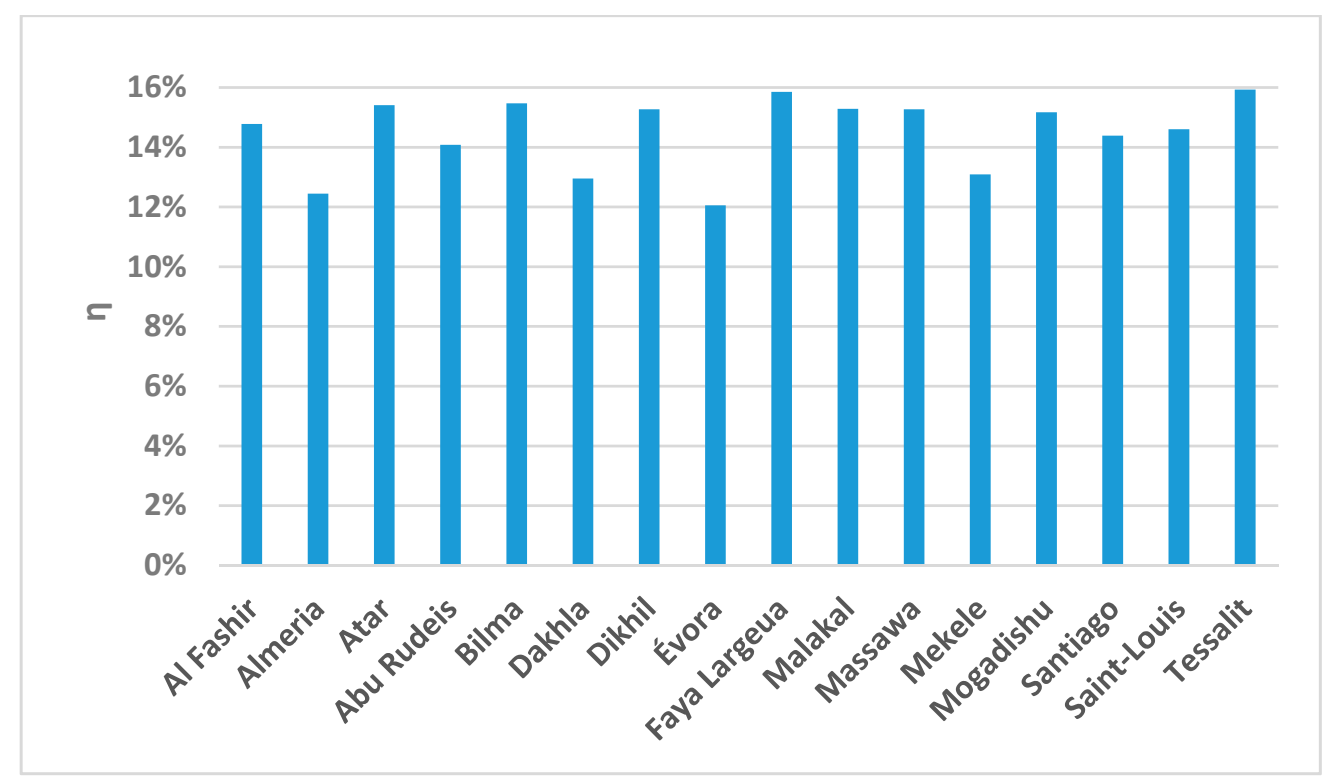

Figure 3. Efficiency of solar distillation plants for the sites studied, calculated with annual weather values.

Among the chosen sites of Table 2, the most and the least suitable for setting up solar distillation plants are, respectively, Faya Largeua and Évora. For both these sites, Figure 4 shows the monthly output of water and includes the monthly average air temperature, whereas Figure 5 shows the monthly output of water and includes the monthly average value of $G$. 


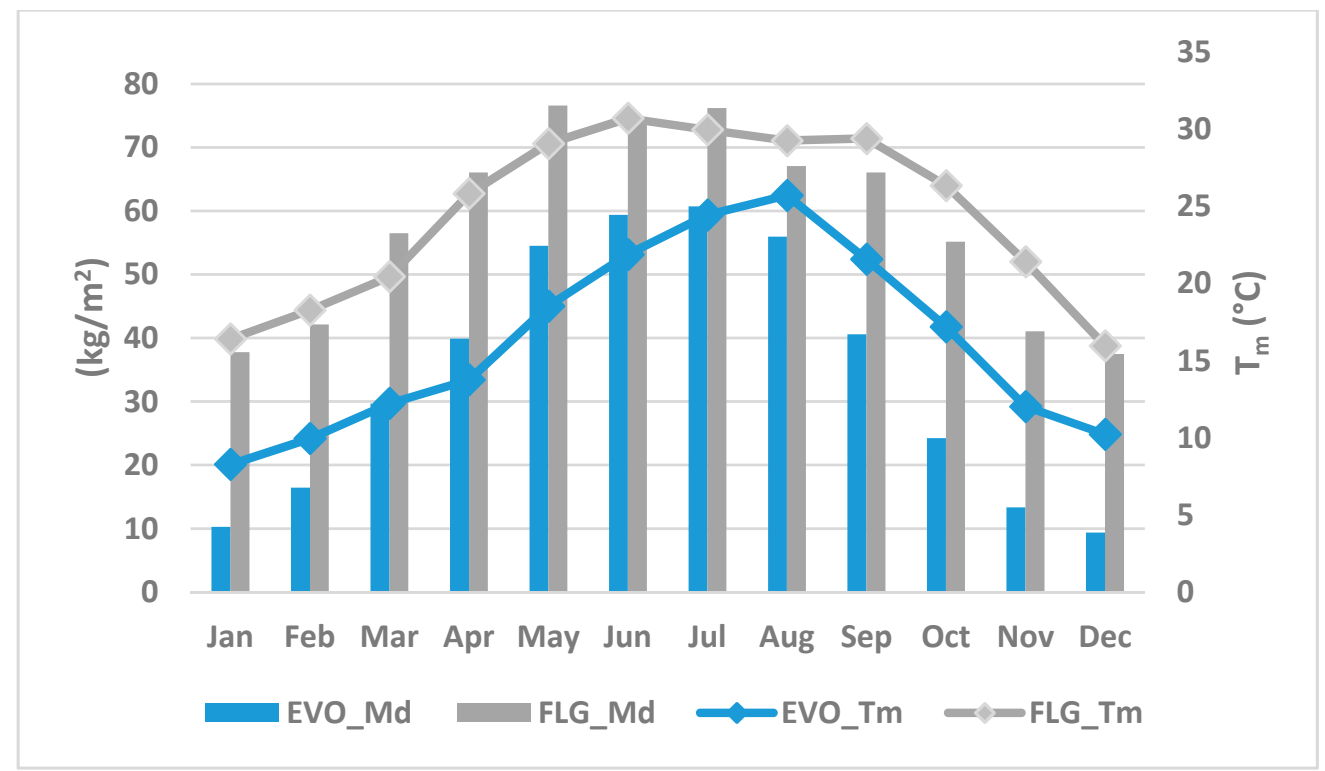

Figure 4. Monthly output of distilled water for Faya Largeua and Évora and the corresponding monthly average air temperature.

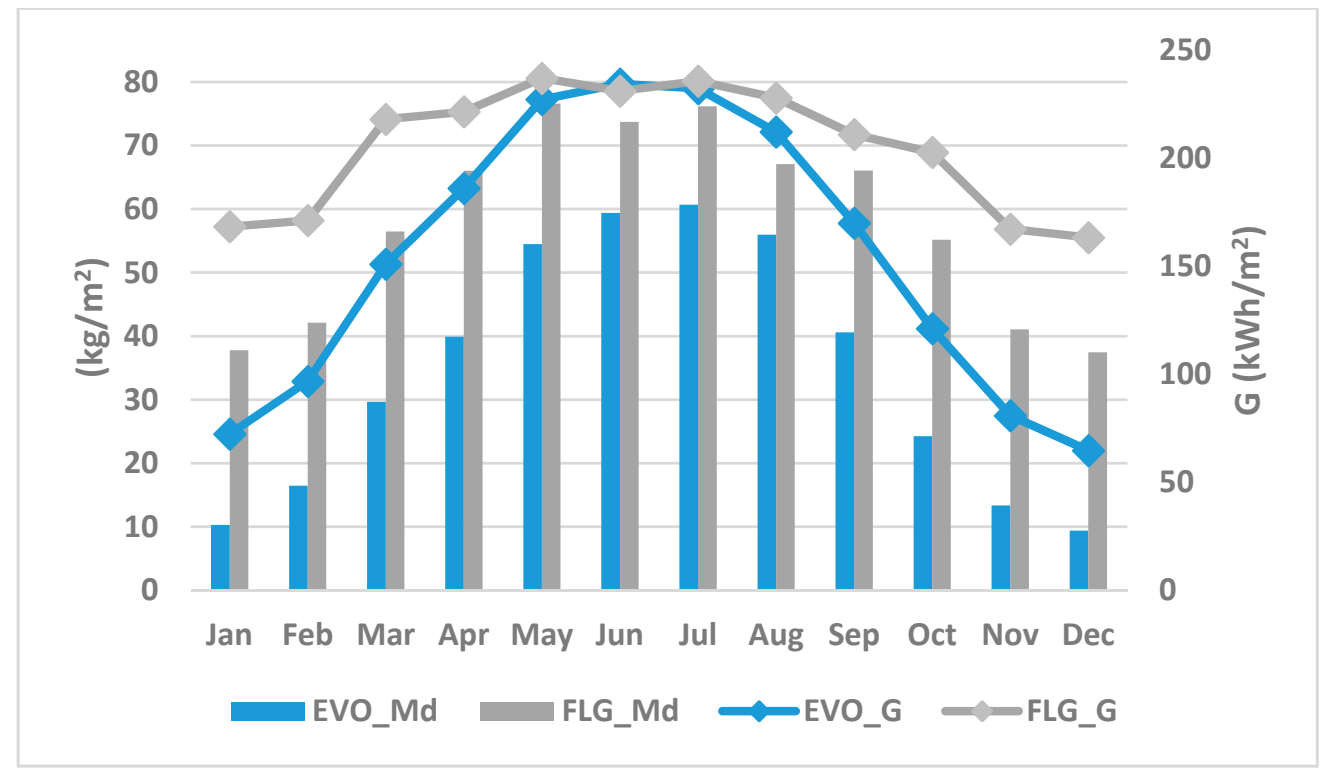

Figure 5. Annual output of distilled water for Faya Largeua and Évora and the corresponding monthly average value of $G$.

Figure 6 shows for the site with the highest water output, Faya Largeua, the monthly values of water output for two different situations: the minimum value and the actual value of the convection coefficient $h_{(c-a)}$ (see Equation (8)).

It is clear from previous figures that the productivity and the efficiency of solar distillers are higher for higher values of either irradiation $G$ or average temperature $T_{m}$. Besides, the productivity and the efficiency of solar distillers increase as the convection coefficient $\mathrm{h}_{(\mathrm{c}-\mathrm{a})}$ drops. Generally, for the sites studied, when $h_{(c-a)}$ drops from the actual to the minimum value, the increase of productivity is around 10\%: for the case of Faya Largeua, such an increase is $12.3 \%$. Thus, some expedients should be 
adopted to decrease, or even eliminate, the velocity of the wind over the distillers. Such expedients can be hedgerows, concrete barriers, etc.

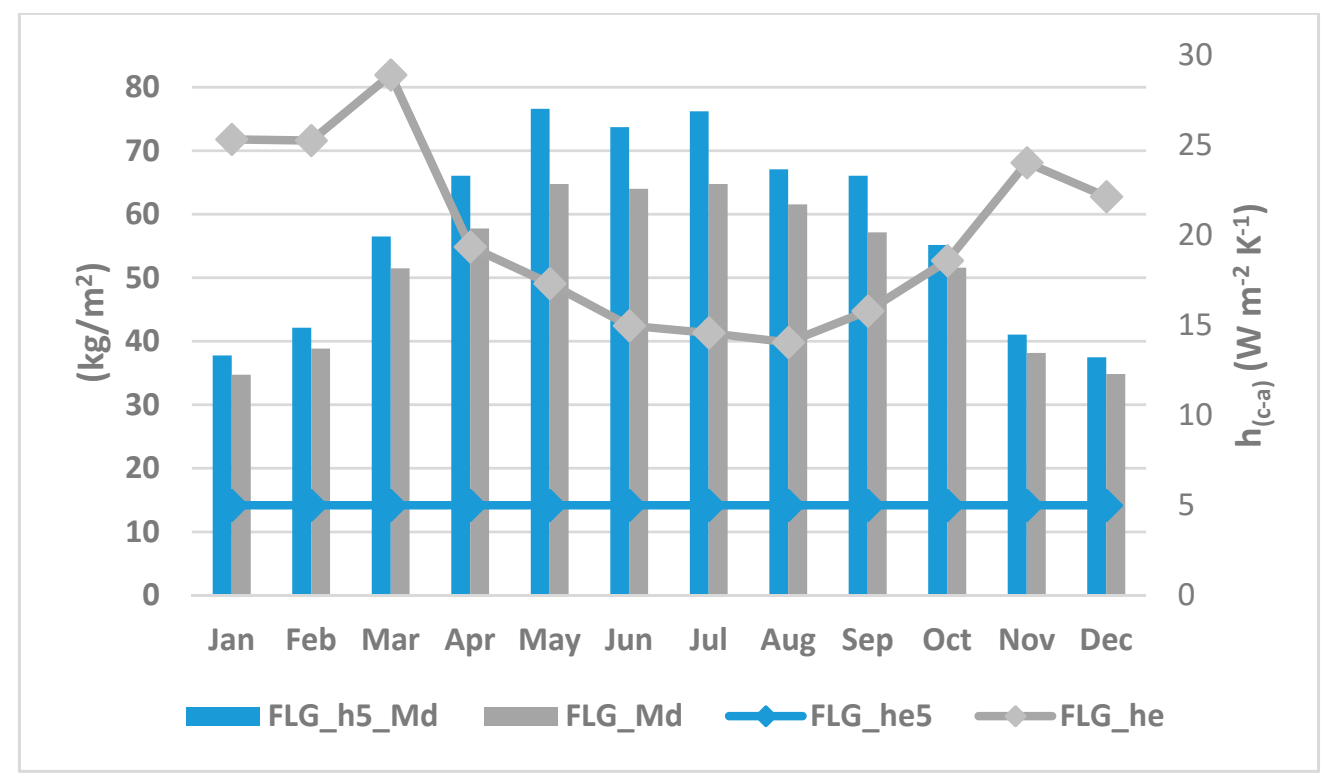

Figure 6. Comparison of the monthly output of distilled water for Faya Largeua with $h_{(c-a)}=5 \mathrm{~W} / \mathrm{m}^{2} / \mathrm{K}$ and $h_{(c-a)}$ obtained with the local wind speed measured.

\subsection{Economics}

An economic analysis was made for the sites referred to in Table 2, with the more important results presented in Table 5. The water annual production was drawn from Figure 2. The average costs of water for consumers were obtained from potable water suppliers: TCO, NPV for twenty years, IRR, and payback result, respectively, from Equation (12), Equation (14), Equation (16), and Equation (17).

It is important to stress that the costs of water presented in Table 5 are subsidized by the abovementioned governments.

Values of Table 5 are, at least, discouraging for poor communities of the Third World tormented by a lack of drinkable water.

Clearly, water can be obtained with distillers made with cheap materials found locally and by local unskilled people; such distillers will be affordable by poor communities, but their performance will be poor. Meanwhile, the performance and economic analyses of such distillers are impossible to calculate because (i) there is an enormous array of materials more or less suitable for the construction of distillers, and consequently, more or less expensive, and (ii) the unskillfulness of people is disputable.

So, the results presented in Table 5, however discouraging, were obtained with the underlying scope to obtain distiller with the highest efficiency, manufactured with prices current at Cabo Verde.

Anyway, from the values of payback of Table 5, it is clear that solar distillers are only suitable for domestic water production where other production methods are unavailable. 
Table 5. Economic analysis summary.

\begin{tabular}{|c|c|c|c|c|c|c|}
\hline Location & $\begin{array}{l}\text { Average Cost of } \\
\text { Water }\left(\boldsymbol{\epsilon} / \mathrm{m}^{3}\right)\end{array}$ & $\begin{array}{c}\text { Water Annual } \\
\text { Production }\left(\mathrm{L} / \mathrm{m}^{2}\right)\end{array}$ & $\begin{array}{c}\text { TCO } 20 \\
\text { Years }\left(\boldsymbol{\epsilon} / \mathrm{m}^{2}\right)\end{array}$ & $\begin{array}{c}N P V 20 \\
\text { Years }\left(\boldsymbol{E} / \mathrm{m}^{2}\right)\end{array}$ & $\operatorname{IRR}(\%)$ & $\begin{array}{c}\text { Payback } \\
\text { (Years) }\end{array}$ \\
\hline Al Fashir & $0.766^{1}$ & 642.6 & \multirow{16}{*}{270.1} & -234.40 & - & 369 \\
\hline Almeria & 0.699 [43] & 420.1 & & -247.30 & - & 619 \\
\hline Atar & $5.952^{2}[44]$ & 644.4 & & -177.85 & -22.1 & 47 \\
\hline Abu Rudeis & $0.167[45]$ & 545.4 & & -251.27 & - & 1996 \\
\hline Bilma & 0.218 [46] & 651.4 & & -250.27 & - & 1280 \\
\hline Dakha & 0.460 [47] & 457.9 & & -248.65 & - & 810 \\
\hline Dikhil & 0.448 [48] & 680.9 & & -247.07 & - & 596 \\
\hline Évora & 0.507 [49] & 414.4 & & -248.93 & - & 865 \\
\hline $\begin{array}{c}\text { Faya } \\
\text { Largeau }\end{array}$ & $0.766[50]$ & 695.8 & & -242.60 & - & 341 \\
\hline Malakal & $0.766^{1}$ & 619.4 & & -243.75 & - & 383 \\
\hline Massawa & $0.448^{3}$ & 680.9 & & -247.07 & - & 596 \\
\hline Mekele & $0.448^{3}$ & 560.5 & & -248.13 & - & 724 \\
\hline Mogadishu & $0.448^{3}$ & 583.0 & & -247.93 & - & 696 \\
\hline Santiago & $4.23^{4}[40]$ & 562.5 & & -206.40 & - & 76 \\
\hline St. Louis & $5.952^{5}$ & 551.6 & & -188.67 & - & 55 \\
\hline Tessalit & $0.207[51]$ & 683.0 & & -250.28 & - & 1286 \\
\hline
\end{tabular}

${ }^{1}$ Cost from Chad,${ }^{2}$ supply in $200 \mathrm{~L}$ drums, ${ }^{3}$ cost from Djibouti, ${ }^{4}$ auto tank supply, ${ }^{5}$ and cost from Mauritania.

\subsection{Carbon Emissions}

Table 6 contains, for the set of sites studied, the values of Greenhouse Gas (GHG) that would be emitted if the production of the water, instead of being through the solar distillers proposed in this study, was by RO. It is considered that the operation of solar distillers does not emit GHG. The water annual production was drawn from Figure 2, and the consumption of electricity to obtain potable water through RO was assumed $3909 \mathrm{kWh} / \mathrm{m}^{3}$, the same as in Cabo Verde.

Table 6. Carbon emissions analysis summary.

\begin{tabular}{cccc}
\hline Location & $\begin{array}{c}\text { Water Annual } \\
\text { Production }\left(\mathbf{L} / \mathbf{m}^{2}\right)\end{array}$ & $\begin{array}{c}\text { RO Desalinization } \\
\text { Energy Consumption } \\
\left(\mathbf{k W h} / \mathbf{m}^{\mathbf{3}}\right)\end{array}$ & $\begin{array}{c}\text { GHG Avoid 20 Years } \\
\left(\mathbf{k g}_{\mathbf{C O}_{2 \mathrm{e}} \mathbf{~}} / \mathbf{m}^{2} \mathbf{)}\right.\end{array}$ \\
\hline Al Fashir & 642.6 & & 20.1 \\
Almeria & 420.1 & 8.0 \\
Atar & 644.4 & 31.5 \\
Abu Rudeis & 545.4 & 20.2 \\
Bilma & 651.4 & 3909 & 42.4 \\
Dakha & 457.9 & 23.6 \\
Dikhil & 680.9 & 53.2 \\
Évora & 414.4 & 10.2 \\
Faya Largeau & 695.8 & 21.8 \\
Malakal & 619.4 & 48.4 \\
Massawa & 680.9 & 53.2 \\
Mekele & 560.5 & 0 \\
Mogadishu & 583.0 & 45.6 \\
Santiago & 562.5 & 21.5 \\
St. Louis & 551.6 & 27.0 \\
Tessalit & 683.0 & 33.4 \\
\hline
\end{tabular}

Clearly the environmental impact of RO is a drawback of this process when compared with solar distillation. 


\section{Conclusions}

The scarcity of water is a problem of a growing number of regions of the world, which cumulatively are the poorest regions. Solar distillation has higher efficiency as irradiation increases and thermal losses decrease, which means that it is an acceptable desalination process for arid and hot climates.

Typical values of annual water output are in the range of $414 \mathrm{dm}^{3} / \mathrm{m}^{2}$ for Évora and up to $696 \mathrm{dm}^{3} / \mathrm{m}^{2}$ for Faya Largeau; the minimum efficiency found for Évora was $11.5 \%$, and the maximum efficiency found for Tessalit was $15.2 \%$.

However, the payback times for high performance solar distillers are very high, which excludes solar distillation when economic criteria are the only factors to be considered.

Solar distillation is far better than $\mathrm{RO}$, when the environmental impact of GHG is considered. For remote and poor communities, solar distillation is to be considered.

So, as guidelines to decide if solar distillation to obtain fresh water it is important to get positive answers to the following questions:

- Remote places;

- Salt water available;

- High solar irradiation;

- Population with low income;

- Population with poor skills;

- Off-grid places.

Finally, the present study addresses the shortage of fresh water in the growing number of places that comply with the previous guidelines.

Author Contributions: The authors have made equivalent contributions. All authors have read and agreed to the published version of the manuscript.

Funding: This research received no external funding.

Conflicts of Interest: The authors declare no conflict of interest.

\section{Abbreviations}

List of Symbols

A

$\mathrm{CO}_{2 e}$

$c$

CAPEX

F

G

GHG

$i$

IRR

$h$

$h_{f g}$

Lc

$M$

$\dot{M}$

NPV

$n$

OPEX

Area of the basin

Carbon dioxide equivalent emissions

Specific heat

Capital expenditure

Casflow

SolaIrradiation

Grehouse gas

Inflion rate

Internal rate of return

Convection coefficient

Latent heat of evaporation

Characteristic length

Mass

Mass flow rate

Net Present Value

Period

Operational Expenditure $\mathrm{m}^{2}$

$\mathrm{J} \mathrm{kg}^{-1} \mathrm{~K}^{-1}$

$€$

$€$

$\mathrm{W} \mathrm{m}{ }^{-2}$

$\%$

$\%$

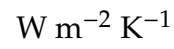

$\mathrm{J} \mathrm{kg}^{-1}$

$\mathrm{m}$

$\mathrm{kg}$

$\mathrm{kg} \mathrm{s}^{-1}$

$€$

year

$€$ 


\begin{tabular}{|c|c|c|}
\hline$p$ & Pressure & $\mathrm{mmHg}$ \\
\hline$P B$ & Payback & year \\
\hline$P V C$ & Polyvinyl chloride & \\
\hline$Q$ & Heat rate & $\mathrm{W} \mathrm{m} \mathrm{m}^{-2}$ \\
\hline$R$ & Revenue & $€$ \\
\hline RO & Reverse osmosis & \\
\hline$T$ & Temperature & K \\
\hline$t$ & Time & $\mathrm{s}$ \\
\hline TCO & Total cost of ownership & $€$ \\
\hline$V$ & Wind velocity & $\mathrm{m} \mathrm{s}^{-1}$ \\
\hline \multicolumn{3}{|c|}{ Subscripts } \\
\hline$a$ & Atmosphere & \\
\hline$b$ & Basin & \\
\hline$c$ & Cover & \\
\hline $\operatorname{conv}$ & Convection & \\
\hline$d$ & Distilled & \\
\hline evap & Evaporation & \\
\hline grd & Ground & \\
\hline$m$ & Average & \\
\hline$n$ & Period & year \\
\hline $\mathrm{rad}$ & Radiation & \\
\hline sk & Sky & \\
\hline$w$ & Water & \\
\hline$w b$ & Wet bulb & \\
\hline \multicolumn{3}{|c|}{ Greek symbols } \\
\hline$\alpha$ & Absorptivity & \\
\hline$\eta$ & Performance & \\
\hline$\theta$ & Angle of incidence & \\
\hline$\rho$ & Reflectivity & \\
\hline$\sigma$ & Stefan-Boltzmann constant & $\mathrm{J} \mathrm{m}^{-2} \mathrm{~s}^{-1} \mathrm{~K}^{-4}$ \\
\hline$\tau$ & Transmissivity & \\
\hline
\end{tabular}

\section{References}

1. Belessiotis, V.; Kalogirou, S.; Delyannis, E. Thermal Solar Desalination: Methods and Systems, 1st ed.; Academic Press: Cambridge, MA, USA, 2016.

2. Cooper, P.I. The absorption of radiation in solar stills. Sol. Energy 1969, 12, 333-349. [CrossRef]

3. Kumar, K.V.; Bai, R.K. Performance study on solar still with enhanced condensation. Desalination 2008, 230, 51-61. [CrossRef]

4. Phadatare, M.K.; Verma, S.K. Effect of cover materials on heat and mass transfer coefficients in a plastic solar still. Desalin. Water Treat. 2009, 2, 254-259. [CrossRef]

5. Duffie, J.A.; Beckman, W.A. Solar Engineering of Thermal Processes, 4th ed.; John Wiley \& Sons, Inc.: Hoboken, NJ, USA, 2013.

6. Harding, J. Apparatus for solar distillation. Minutes Proc. Inst. Civ. Eng. 1883, 73, 284-288. [CrossRef]

7. Telkes, M. Fresh water from sea water by solar distillation. Ind. Eng. Chem. 1953, 45, 1108-1114. [CrossRef]

8. Lof, G.O.G.; Eibling, J.A.; Bloemer, J.W. Energy balances in solar distillers. AIChE J. 1961, 7, $641-649$. [CrossRef]

9. Bloemer, J.W.; Eibling, J.A.; Irwin, J.R. A practical basin-type solar still. Sol. Energy 1965, 9, 197-200. [CrossRef]

10. Talbert, S.G.; Eibling, J.A. Manual on Solar Distillation of Saline Water; NTIS: Springfield, VA, USA, 1970.

11. Hull, J.R. Solar ponds using ammonium salts. Sol. Energy 1986, 36, 551-558. [CrossRef]

12. Hull, J.R.; Bushnell, D.L.; Sempsrote, D.G.; Pena, A. Ammonium sulfate solar pond: Observations from small-scale experiments. Sol. Energy 1989, 43, 57-64. [CrossRef] 
13. Nielsen, C.E. Salinity-gradient solar ponds. In Advances in Solar Energy; Böer, K.W., Ed.; Springer: Boston, MA, USA, 1988; Volume 4.

14. Morse, R.N. The Development of a Solar Still for Australian Conditions; Institution of Engineers: Barton, Australia, 1967.

15. Morse, R.N. The construction and installation of solar stills in Australia. Desalination 1968, 5, 82-89. [CrossRef]

16. Morse, R.N.; Read, W.R.W. A rational basis for the engineering development of a solar still. Sol. Energy 1968, 12, 5-17. [CrossRef]

17. Morse, R.N.; Read, W.R.W.; Trayford, R.S. Operating experiences with solar stills for water supply in Australia. Sol. Energy 1970, 13, 99-103. [CrossRef]

18. Morse, R.N. The theory of solar still operation. In Proceedings of the UN Solar Distillation Panel Meeting, Palo Alto, CA, USA, 20-23 October 1968.

19. Lawand, T. Engineering and economic evaluation of solar distillation for small communities. Presented at the Annual ASME Meeting, Los Angeles, CA, USA, 16-20 November 1969.

20. Lawand, T. Systems for solar distillation. In Proceedings of the Appropriate Technologies for Semiarid Areas: Wind and Solar Energy for Water Supply, Berlin, Germany, 15-20 September 1975.

21. Telkes, M. Solar Stills; Proceedings World Symposium on Applied Solar Energy: Phoenix, AZ, USA, 1956.

22. Hirschmann, J. Evaporación solar y su aplicación práctica en Chile. Scientia 1968, 136, 16.

23. Lof, G.O.G.; Hunter, J.A.; Sieder, E.N. Technical Cooperation on the Solar Distillation Development Program of Spain. In Distillation Digest; Tomalin, P.G., Ed.; Office of Saline Water: Washington, DC, USA, 1970; Volume 1-2, pp. 241-252.

24. Bloemer, J.W.; Collins, R.A.; Eibling, J.A. Study and Field Evaluation of Solar Sea-Water Stills; United States. Department of Commerce. Office of Technical Services: Washington, DC, USA, 1961.

25. Bloemer, J.W.; Irwin, J.R.; Eibling, J.A. 'Second Two-Years' Progress on Study and Field Evaluation of Solar Sea-Water Stills; Battelle Memorial Institute: Columbus, OH, USA, 1964.

26. Eckstrom, R. Design and construction of the Symi still. Sun Work 1965, 10, 6-8.

27. Delyannis, A. Solar stills provide an island's inhabitants with water. Sun Work 1965, 10, 6.

28. Eckstrom, R. New solar stills on Greek islands. Sun Work 1966, 11.

29. Delyannis, A.; Delyannis, E.; Piperoglou, E. Solar distillation developments in Greece. Sun Work 1967, 12.

30. Delyannis, A.; Piperoglou, E. The Patmos solar distillation plant. Sol. Energy 1968, 12, 113-115. [CrossRef]

31. Datta, R.L.; Gomkale, S.D.; Ahmed, S.Y.; Datar, D.S.; Intensity, T.X.S.R. Evaporation of sea water in solar stills and its development for. In Proceedings of the First International Symposium on Water Desalination, Washington, DC, USA, 3-9 October 1965; Volume 2, p. 193.

32. Ahmed, S.Y.; Gomkale, S.D.; Datta, R.L.; Datar, D.S. Scope and development of solar stills for water desalination in India. Desalination 1968, 5, 64-74. [CrossRef]

33. Baum, V.A.; Bairamov, R. Prospects of solar stills in Turkmenia. Sol. Energy 1966, 10-11, 38-40. [CrossRef]

34. Cooper, P.I.; Bairamov, R. The maximum efficiency of single-effect solar stills. Sol. Energy 1973, 15, $205-217$. [CrossRef]

35. Dunkle, R.V. Solar water distillation: The roof type still and a multiple effect diffusion still. In Proceedings of the International Heat Transfer Conference, Boulder, CO, USA, 28 August-1 September 1961; Volume 5, p. 895.

36. Gerador de Preços Para Construção Civil. Cabo Verde. CYPE Ingenieros, S.A. Available online: http: //www.caboverde.geradordeprecos.info/ (accessed on 17 July 2019).

37. Chad: Inflation Rate from 1984 to 2024. Available online: https://www.statista.com/statistics/529342/inflationrate-in-chad/ (accessed on 20 July 2019).

38. Portugal: Inflation Rate from 1984 to 2024. Available online: https://www.statista.com/statistics/529342/ inflation-rate-in-portugal/ (accessed on 20 July 2019).

39. Al-Karaghouli, A.; Kazmerski, L.L. Energy consumption and water production cost of conventional and renewable-energy-powered desalination processes. Renew. Sustain. Energy Rev. 2013, 24, 343-356. [CrossRef]

40. Relatório e Contas 2018. Available online: http://www.electra.cv/index.php/2014-05-20-15-47-04/relatoriossarl/ (accessed on 20 October 2019).

41. $\mathrm{CO}_{2}$ Emissions from Fuel Combustion 2018 (with 2016 Data). Available online: https://webstore.iea.org/co2emissions-from-fuel-combustion-2018 (accessed on 20 October 2019).

42. Repository of Free Climate Data for Building Performance Simulation. Available online: http://climate. onebuilding.org/ (accessed on 15 July 2019). 
43. Tarifas de Abastecimiento Almeria. Available online: https://www.aqualia.com/documents/373313/374060/ Almer\%C3\%ADa_TARIFAS+ABASTECIMIENTO.pdf/d9a04334-9c2a-425c-924d-4866c7a10802/ (accessed on 17 October 2019).

44. La Distribution d'eau Potable Dans la Ville de Nouakchott, Mauritanie. Analyse des Points de Vente d'eau. Available online: https://www.pseau.org/outils/ouvrages/gret_distribution_eau_potable_ville_nouakchott_ analyse_points_d_eau.pdf (accessed on 17 October 2019).

45. Global Water Intelligence. Available online: https://www.globalwaterintel.com/news/2017/31/egypt-to-slashsubsidies-in-water-and-wastewater?dm_i=36G3,IGWK,2MX9NG,1XJV0,1 (accessed on 17 October 2019).

46. SEEN. Available online: https://www.seen-niger.com/fr/activites/relation-clientele/nos-tarifs (accessed on 17 October 2019).

47. Chohin-Kuper, A.; Strosser, P. Water pricing in Europe and around the Mediterranean Sea: Issues and options. Presented at 4th EWA Brussels Conference, Brussels, Belgium, 8 November 2008.

48. NIPA - National Investment Promotion Agency. Available online: http://www.djiboutinvest.com/index.php? option=com_content\&view=article\&id=289\&Itemid= (accessed on 17 October 2019).

49. Tarifário dos Serviços de Abastecimento de Águas, Saneamento de Águas Residuais e Gestão de Resíduos Urbanos do Município de Évora. 2019. Available online: http://www.cm-evora.pt/pt/servicos/aguas/Paginas/ Tarif\%C3\%A1rios.aspx (accessed on 17 October 2019).

50. UNHabitat. Available online: http://unhabitat.org/wpcontent/uploads/2015/12/Soci\%C3\%A9t\%C3\%A9\% 20Tchadienne\%20des\%20Eaux\%20(Chad).pdf (accessed on 17 October 2019).

51. Fixation des Tarifs de L'Eau Potable Applicables. Available online: http://www.creemali.ml/documents/ TARIFS_EAU_2013.pdf (accessed on 17 October 2019).

(C) 2019 by the authors. Licensee MDPI, Basel, Switzerland. This article is an open access article distributed under the terms and conditions of the Creative Commons Attribution (CC BY) license (http://creativecommons.org/licenses/by/4.0/). 